\title{
USING TEACHER'S INDIRECT FEEDBACK STRATEGY TO IMPROVE THE STUDENTS' ABILITY IN WRITING DESCRIPTIVE TEXT FOR THE FIRST GRADE STUDENTS OF SMAN 1 BENGKULU TENGAH IN THE 2016/2017 ACADEMIC YEAR.
}

\author{
Yudha Septian Kurniawan \\ yudhaseptiankurniawan@gmail.com \\ Bambang Suwarno \\ wdsaraswati@gmail.com \\ Arono \\ arono@unib.ac.id \\ University of Bengkulu
}

\begin{abstract}
This research aimed to improve students' ability in writing descriptive text by using teacher's indirect feedback strategy for the first grade of SMAN1 Bengkulu Tengah in the 2016/2017 academic year. The subjects consisted of 30 students of Science Program. The research was conducted in two cycles, namely, each cycle consisted of planning, action, observation and reflection. Before the first cycle, the researcher gave pre-assessment. The result showed that the students' mean score was 44,00 in absolute range, or 60,00 in relative range (poor category). After implementing cycle one, the students' mean score in writing skill showed a little progress, especially in content's aspect. On other hand some students were still lacking in vocabulary and language use aspects. In the second cycle, the teacher and the researcher focused to gave the students materials of two aspects above. The result was that improved to the students' mean score : 60,76 in absolute range or 83,00 in relative range (very good category). The students' responses were possitive toward this strategy. It was concluded that teacher's indirect feedback strategy could improve students' ability in writing descriptive text and it could be developed to other students.
\end{abstract}

\section{Key word: Writing ability, descriptive text, teacher's indirect feedback strategy.}

\begin{abstract}
ABSTRAK
Penelitian ini bertujuan meningkatkan kemampuan siswa dalam menulis teks descriptif dengan menerapkan strategi umpan balik secara tidak langsung oleh guru pada kelas X IPA 1 SMA Negeri 1 Bengkulu Tengah tahun pelajaran 2016/2017. Subjek penelitian ini terdiri atas 30 orang siswa. Penelitian ini dilakukan dalam dua siklus yaitu, masing-masing siklus terdiri atas perencanaan, pelaksanaan/tindakan, observasi dan refleksi. Sebelum menerapkan siklus 1, peneliti mengadakan tafsiran pertama. Hasilnya menunjukkan bahwa nilai rata-rata siswa adalah 44,00 atau 60 dengan kisaran penilaian 10-100 (Memprihatinkan). Setelah penerapan siklus 1, nilai rata-rata siswa pada kempampuan menulis mengalami peningkatan, terkhusus pada aspek isi tulisan, namun di sisi lain, masih ada beberapa siswa yang masih terkendala pada aspek kosa kata dan pemilihan bahasa dalam menulis. Pada siklus 2, peneliti dan guru bidang studi lebih menfokuskan pemberian materi tentang kedua aspek penulisan yang masih dianggap lemah tersebut. Hasilnya nilai rata-rata siswa pada siklus 2 meningkat yaitu 60.76 atau 83 dengan
\end{abstract}


kisaran penilaian 10-100 (sangat baik). Ini membuktikan bahwa kemampuan menulis siswa mengalami peningkatan lebih baik dari siklus sebelumnya. Siswa juga memiliki respon yang positif terhadap strategi yang diajarkan ini. Hal ini dapat disimpulkan bahwa dengan menggunakan umpan balik secara tidak langsung oleh seorang guru dapat meningkatkan kemampuan siswa dalam menulis teks descriptif dan hal tersebut dapat dikembangkan ke siswa yang lain.

\section{Kata Kunci: Kemampuan menulis, Teks descriptif, Strategi upan balik guru secara tidak langsung.}

\section{A. Introduction}

English is as a global language sets the important role in teaching English at school from elementary school until senior high school and even at university. From these facts, students are not only expected to speak English fluently and accuretely but they also have to be able to fulfill four language skills; speaking, writing, reading, and listening. These four skills are integrated and related to each other.

Based on the curriculum of 2013, all skills in teaching and learning English that are integrated each other must be learnt and taught by both student and teacher, including writing skill. Writing helps the students master the other skills and of course in mastery of English completely.

The students are sometimes afraid and shy to speak what they want to say but they can tell what they think and what they want to say into draft or writing before speaking. Thus, if the students are having problem in expressing an idea, he/she can write it down. Then, the student itself or possibly the reader will understand it

Roger (2001:20) said that some feedback from teacher serves unhelpful feedback to student; they are too generalized or unclear, subjective and focused on some aspects of performance that make the students cannot change. That is why giving feedback to students' writing is important skill that is seldom taught. Through feedback, we can help students compare their own performance with the ideal and to diagnose their own strength and weaknesses.

The researcher assumed that indirect feedback was one of positive support that could be given by an English teacher to their students in order to improve students' writing and minimize their errors. Beside that there were some reasons why indirect feedback was so helpful for the students' writing, it was because oral/direct feedback could be durable, but it would keep only in mind of receiver and the feedback could just lost in certain time. In contrast, the indirect feedback, the thought and comment would be saved for a very long time in the memories. Indirect feedback would be read and resistant.

The researcher assumed that also the students should focus with writing skill in the level of Senior High School. Because the students were be prepared to continue their study at the university level where writing was really required especially writing related paper of scintific research for their study. In regarding interview at the first observation with English teachers at SMA Negeri 1 Bengkulu Tengah, actually the students were really interested in learning English but sometimes they found it difficult in writing, especially in writing descriptive paragraph. Almost of their problems were poor vocabulary, grammar errors, spelling and also punctuation errors. 


\section{B. Research Method}

The design of this research was classroom action research because the teacher was directly involved in improve students' ability by doing self-reflection. According to Julian Hermida in Gwyn Mettetal (2001), Classroom Action Research is a method of finding out what works best in your own classroom so that you can improve student learning.

This action research aimed to follow the process of the improve students ability and was conducted by the teacher itself by reflected his /her work and tried to improve his/her way in teaching writing especially to gave indirect feedback. Therefore, both teacher and student could be improved.

The cycle consists of planning, action, observation, and reflection. The model that was proposed for teacher in doing action research follows the cyclical structure outlined by (Kemmis and Mc Taggart in Stringer, 1999: 18).

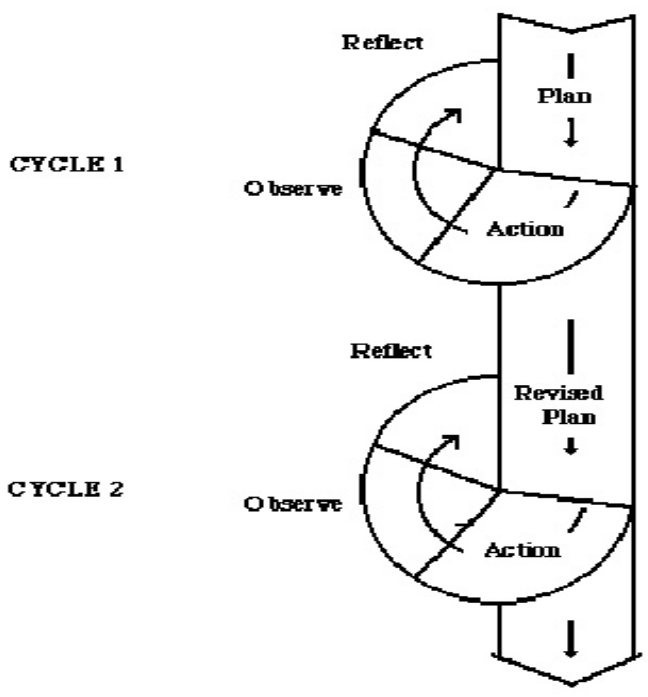

Figure.1. Cycle Model adapted by Kemmis and McTaggart

\section{Findings and Discussions}

Based on the observation of the result of students' composition pre-assessment before conducting the action, it found that there were several problems related to the aspects of evaluation in writing (Content, Language Use, and Vocabulary). The students were still weak in writing descriptive text. In fact can be seen this charts as follow:

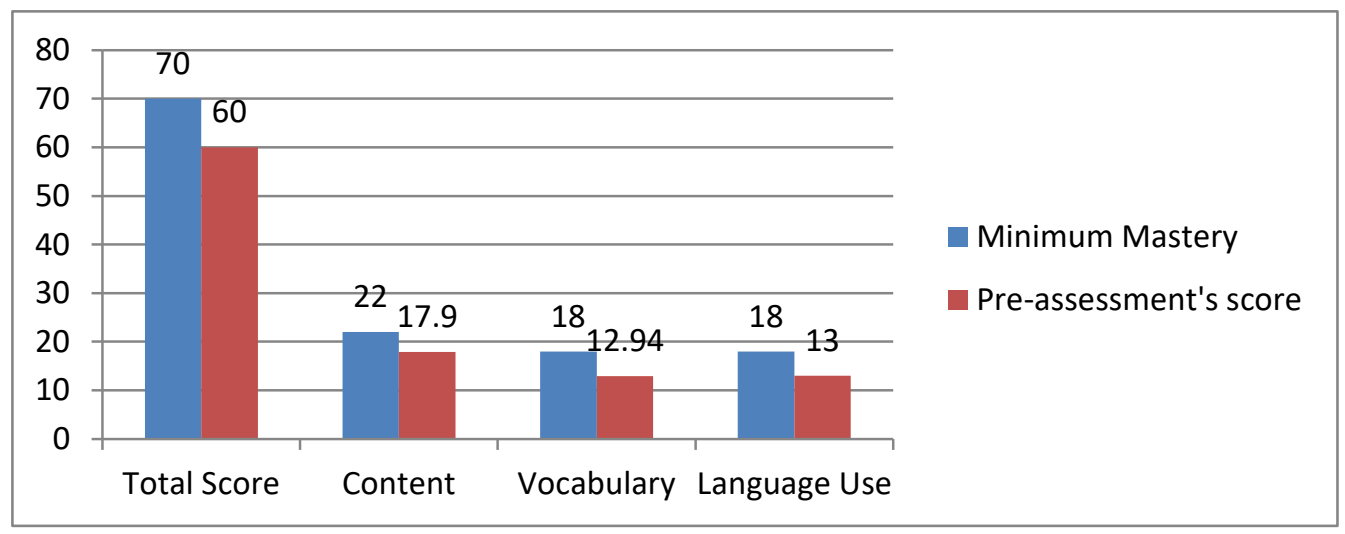

Chart.4.1 The students' mean score on pre-assessment result. 
The chart explained about the students' result on pre-assessment if we compared with minimum mastery at the school. The result of mean score from students' score devided by total of the students. The researcher found that the students' score in writing was still lack and needed improvement.

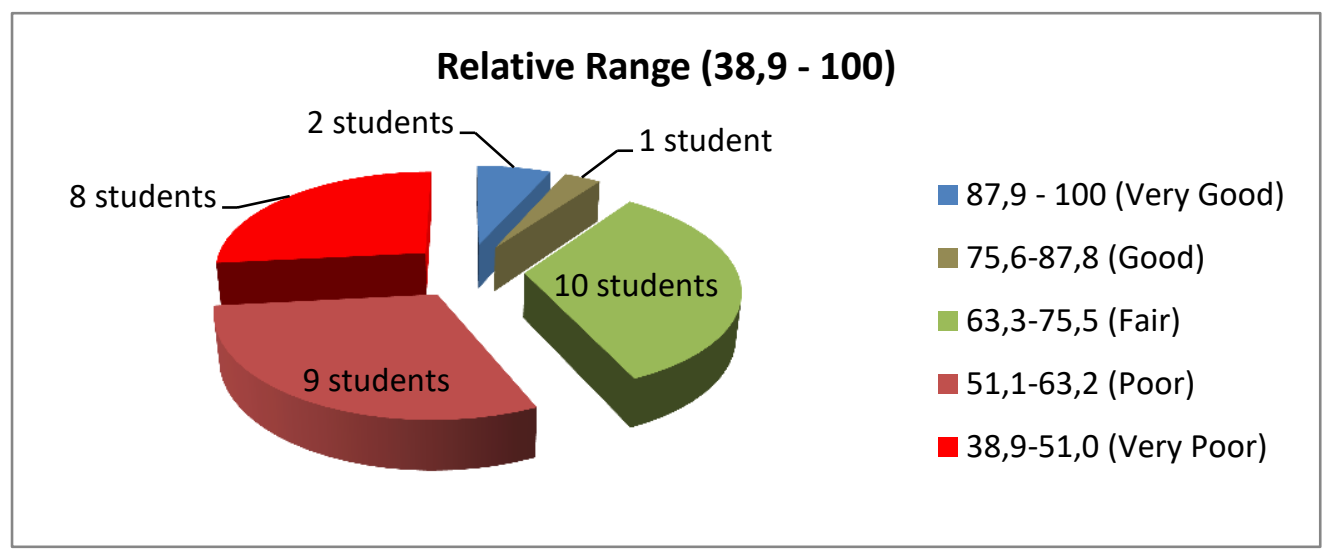

Chart.4.2. Total of the students' pre-assessment based on category

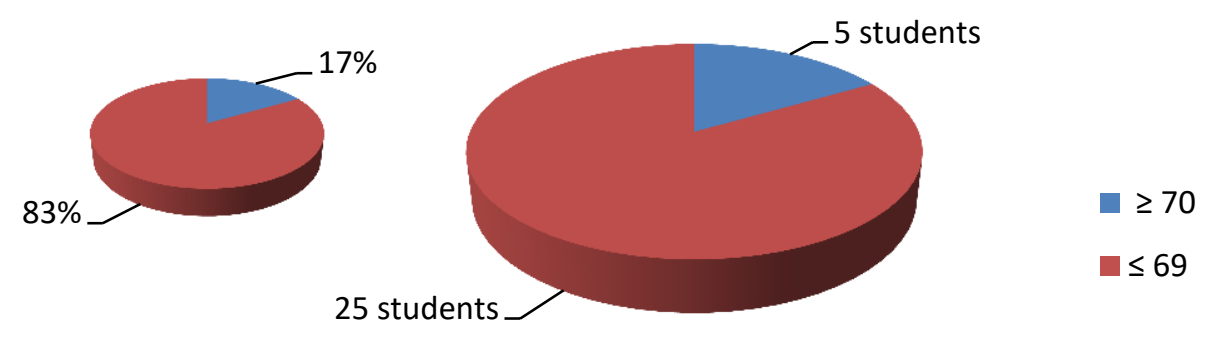

Chart.4.3. Result of the students' pre-assessment based on minimum mastery

The chart explained about the result of pre-assessment when the researcher made his first observation. The researcher want to know where the students' weak in writing skill. The result was 10 students "fair" category or gots absolute range " $47,5-56,6$ " in relative range "63,3 - 75,5". Then, 9 students gots "poor" category, 8 students gots "very poor" and the other gots "good and very good" category. If we concluded score based on minimum mastery or standard score of writing subject at the school ( $\geq 70$ ), there were 25 students or $83 \%$ that was declared "Not Passed" in writing skill. So, it made sure the researcher doing this research.

\section{Activities of the first cycle}

Based on observation that had been done in the first cycle, the first and second meeting did not get any difficulties to transfer the material and students also often asked about some question such as what the descriptive text is, how they can start to write and what for the copy of marking scheme had been given to them, etc.

The problem appeared when the teacher asked them to write their $1^{\text {st }}$ draft in the third and fourth meeting. The students wrote a composition based on teacher's instruction. In this time, they had to write a descriptive text about the most important person in their life. During the process, the students got difficulties to express their ideas into writing. They still had not understand yet about descriptive text even the teacher had 
explained them in previous meeting and some of them made it in disorder content and Language Use. It can be seen on student's composition in appendix 12, draft 1.

In the first draft, students did not make a good improvement because they still lack in part Content and language use. When teacher checked their work before giving indirect feedback on their $1^{\text {st }}$ draft, the fact that they confused how to move from the first paragraph to the next paragraph and also how to differentiate the general description-detail descriptionsconclusion.

As an example, it can be seen one of student's composition. In the first draft, this student composed less content and poor language use. Actually the student already had good vocabulary but the student got problem how to make an interst content and develop the idea in the composition. Here is an untitled composition (appendix 11, draft 1) :

"hai my name is Ridwan Nilhakim and you can call me Ridwan. I live in Halmahera Street komplek Diknas No.171. I have one brother. He is a policeman, my brother old 20 years old I love my brother. And next time I want to a police too.

I am a man, my school is SMAN 1 Bengkulu Tengah my class in X IPA . I like my class. because they want to real friendship to me and nice with all. Every in class we play and study together"

Some mistakes had been made in language use aspect and content. In language use, the mistakes were bolded. It can be seen that the student did many mistakes from beginning until the end of sentences. Here, when the teacher gave the indirect feedback to a student's writing draft.

"hai ${ }^{S P}$ my name is Ridwan Nilhakim and you can call me Ridwan. I live in Halmahera Street komplek Diknas No.171 $1^{(P U N C)}$ I have one brother. He is a policeman, my brother old 20 years old ${ }^{V T}$ I love my brother. And next time ${ }^{W C} I$ want to police too ${ }^{V T}$.

I am a man, my school is SMAN 1 Bengkulu Tengah ${ }^{(P U N C)}$ my class in X IPA1 ${ }^{V T}$. I like my class. ${ }^{(P U N C))}$ because they want to real friendship (unclear ${ }^{m e a n i n g}$ to me and nice with all. Every in class we play and study together ${ }^{G R}$ "

For the content's aspect, this student did not write the composition based on the generic structure of descriptive text. Those sentences could be an introduction, description or even conclusion. It means that, this student had not made a good improvement that is related to the generic structure and language feature (language use) of descriptive text. In developing the idea, the student was still lack of vocabulary and the student did not put the title of composition. Moreover, the sentences were still choppy even the reader might be able to understand it. In language use, it can be seen that some mistakes were occurred in composition, for example SP/spelling (hai, u, wit), WC/word choice (next time), PUNC/punctuation (period, comma), and VT/ verb tense (my brother old 20 years old, my class in X IPA1). 
Another students sample was taken in the same problem. Her name is Sartika Indah Lestari. In here the student wrote a paragraph with the theme about "My Lovely Family". Here is a composition entitled "my brother":

I have brother, But one that I'm very like. He have name is Ramadhan. He is policeman. He is chil second from fife collegues. He live in jl. Pratu aidit number 12. he is the most important person in my life because he that always to pay me to school. He already have family now.

He have one boy. He very like to play by her boy. Bedidest its he also like sports. Sports that he likes is badminton, football and tabletennis. Although he often sports but her person very biggest and fat. He don't like if see peoples that always to play dice. He always teach A me about lessons, that I don't know. So he don't like if I don't go to school one day. He to strike me if I don't bring about it.

This composition is different from above sample. This student wrote two paragr aphs that talked about "Brother". From the title, it can be seen that the student had a good idea to write. This student wrote some ideas about "brother" that obviously, it was still general and needed to be improved. Even the ideas were choppy in the first draft but in the next draft, this student was able to make an average composition. From language use aspect, some mistakes were occurred in composition, it can be seen in bolded word and codes/symbols here :

I have brother. ${ }^{(P U N C)}$ But one that I'm very ${ }^{(N N)}$ like. He have name is Ramadhan ${ }^{(S / V A)}$. He is policeman. He is chil ${ }^{(S P)}$ second fromfife ${ }^{(S P)}$ collegues $^{(W C)}$. He live ${ }^{(S / V A)}$ in jl. Pratu aidit number 12 . he is the most important person in my life because he that $^{(N N)}$ always to ${ }^{(N N)}$ pay me to school. He already have ${ }^{(S / V A)}$ family now ${ }^{N P}$.

He have (S/VA) $_{\text {one boy. He very }}^{(W 0)}$ like (S/VA) $^{(S o}$ play by her boy. Bedidest ${ }^{(S P)}$ its $^{(W C)}$ he also like ${ }^{(S / N A)}$ sports. Sports that he likes is badminton, football and tabletennis ${ }^{(G R)}$. Although he often sports ${ }^{(W C)}$ but her person very biggest and fat ${ }^{(G R)}$. He don' $t^{(S / V A)}$ like if see peoples ${ }^{(W C)}$ that always to $^{(N N)}$ playdice ${ }^{(P U N C)}$. He always ${ }^{(N N)}$ teach $^{(S / N)} A$ me about lessons, that I don't know. So ${ }^{(P U N C)}$ he don't(SNA) like if I don't go to school one day. He to strike me if I don't bring about it ${ }^{\text {?????). }}$

Mostly, the mistakes are about the subject and verb agreement (S/VA), punctuation (PUNC), word choice (WC), word order (WO), Spelling (SP), not necessary word (NN). (Appendix, draft 1).

The third and fourth meeting activities focused on students' composition, those are distributing students' $1^{\text {st }}$ draft, discussing about the problem on their writing and revising it based on the feedback given. Some problems appeared during the process of writing $2^{\text {nd }} \mathrm{draft}$ as a revision of $1^{\text {st }}$ draft. They often asked about the English of some words or what vocabulary that they can use in a sentence and many other problems found when the process was over. An example of students' writing can be seen as follow:

"Hai, my name is Rajes Husain and you can call me Rajes. I live in Nakau street No.12

I have one cousin. She now live in Yogjakarta. She college in Universitas Gajah Mada. She is 20 years old. I was born in Curup 27 September 2000. and I'm 16 years old now. 
Bay the way, now I'm school in SMA 1 BENTENG. I'm in $X$. I really like my class, yo know why? Because my friend in class reall friendship and nice with all.

I'm mosleam and I really like reading. My favored book is VA novel and all book from Indonesia.

I like sport, watching TV and listening music

I like film horror, action, and romantic comedy. I really like watching film because that can make me fresh and eliminate to against the stomach and stress.

And now I'm 16 years old in this years my parent really nice to me. Him love me so much" (Appendix 15, draft II).

For more understand about the mistakes of the student's writing above, the researcher makes it with codes/symbols in indirect feedback. It can be seen as follow :

“(SP) $\underline{\text { Hai, }}$, my name is Rajes Husain. ${ }^{(P U N C)}$ and you can call me Rajes. I live ${ }^{(P R E P)}$ in Nakau street No. $12^{(P U N G)}$

I have one cousin. She now live ${ }^{(S / V A)}$ in Yogjakarta. She college ${ }^{(W C)}$ in Universitas $^{(S P)}$ Gajah Mada. She is 20 years old. I was born in Curup 27 September 2000. ${ }^{(P U N C)}$ and I'm 16 years old now. ${ }^{(S P)}$

${ }^{(S P)}$ Bay the way, now I'm $\underline{\text { school }}^{(N N)}$ in SMA 1 BENTENG. I'm in $X$. I really like my class, ${ }^{(S P)}$ yo know why? Because my friend in class reall ${ }^{(S P)}$ friendship and nice with all ${ }^{(? ? ?)}$.

I'm mosleam ${ }^{(S P)}$ and I really like reading. $\underline{M y}$ favorid $^{(S P)}$ book is VA novel and all book $^{(G R)}$ from Indonesia.

\section{$\underline{\text { I like sport, watching TV and listening music }}{ }^{(M O V E ~ T H I S)}$}

I like film horror, action, and romantic comedy. I really like watching film because that can make me fresh and eliminate $^{(W C)}$ to against the stomach and stres $^{(? ? ?) \text {. }}$

And now I'm 16 years old in this years my parent really nice to me. ${ }^{(W C)}$ Him love me so

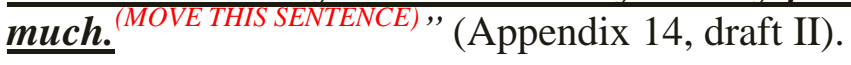

The sample writing above showed that some mistakes still occurred,mostly the mistakes were in language use aspect, while in content's aspect, this composition is better than in the first draft. To compare the first draft and the second draft, it can be seen in appendix 14 .

For more clear of the problem in the cycle 1, the researcher made the charts as follow

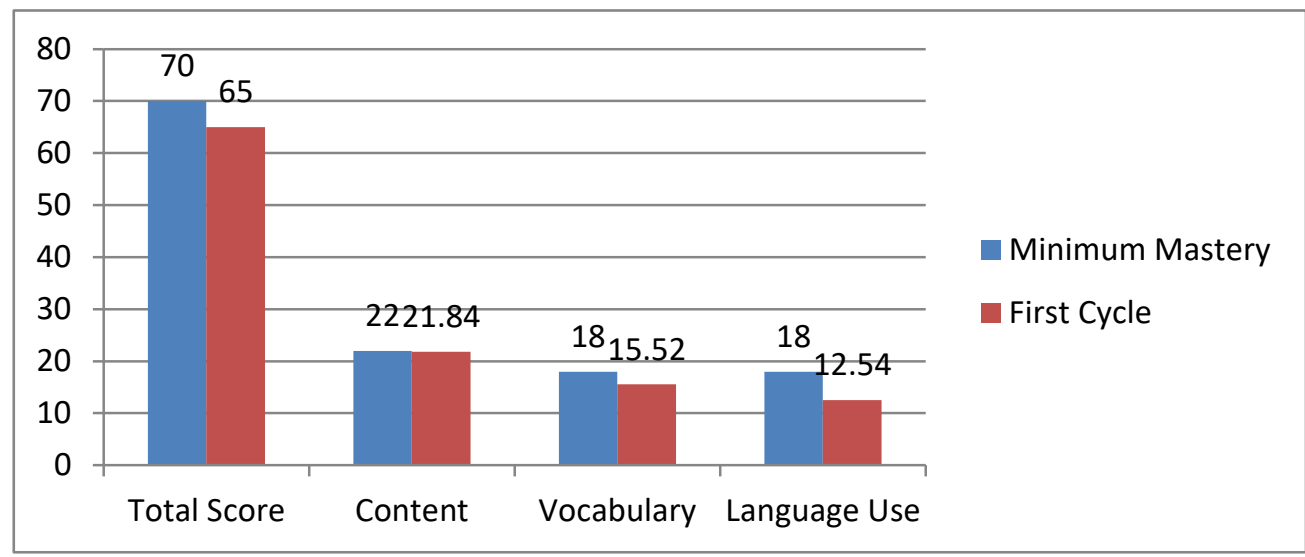

Chart.4.4 The students' mean score on first cycle result. 
This chart is same like chart 4.1, it explained about mean score of absolute range from three aspects of writing and total score that researcher made on first cycle to the students. The result of mean score from students' score devided by total of the students. If we compared with minimum mastery at the school, the result has a significat score, even some students still weak at the other aspects of writing.

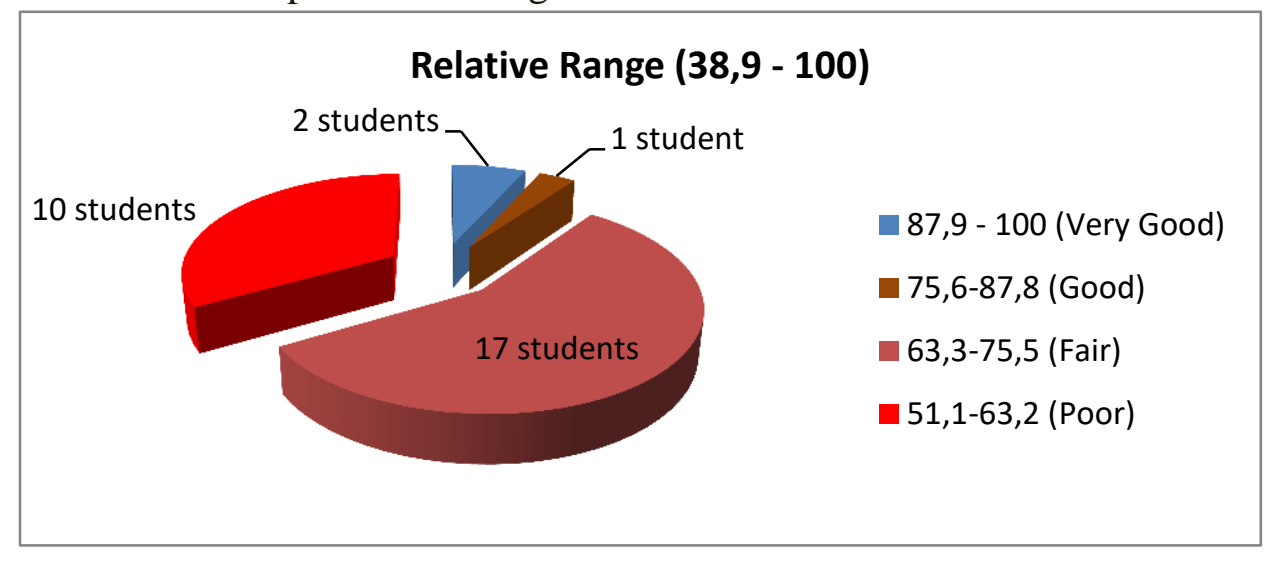

Chart.4.5. Total of the students' first cycle based on category

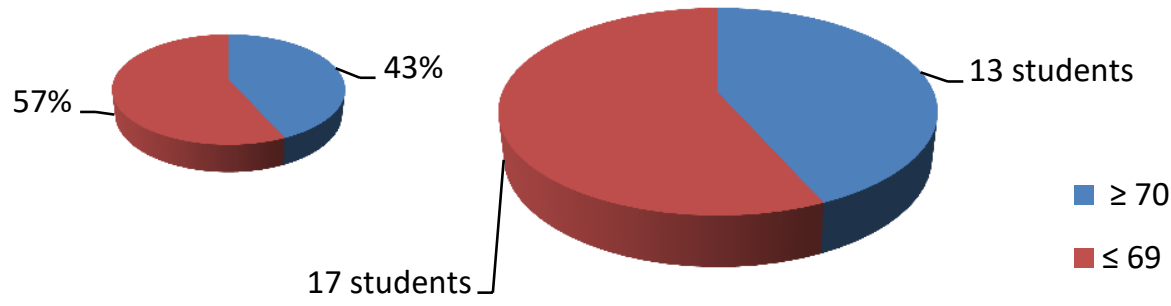

\section{Chart.4.6. The result of the students' first cycle based on minimum mastery}

This chart explained about the result of first cycle. The result were 17 students "fair" or gots absolute range " $47,5-56,6$ " in relative range " $63,3-75,5$ " and it was include a fair category. Then, 10 students were still "poor" or gots absolute range under " 47,4 " in relative range "63,2" and the other has a good and very good category. However, there was no student that gots very poor category on this cycle, but 17 students or $57 \%$ of the students were still declared "Not Passed" in writing skill. So, it made sure the researcher doing second cycle and focus on the weak aspect.

From the result also, it increased but it was still far from the target want to be achieved. Based on the overall process in cycle I, The researcher found that some problems appeared during the process of writing from $1^{\text {st }}$ until $4^{\text {th }}$ meeting in the first cycle. First, the problem came from their vocabulary problem. During the process of writing, the students often asked about some words in English or what vocabulary they can use in their sentences.

For example, the question "sir, what english for "ibuku baik sekali"?."Another question is "what good language for " teman kelas", friend class atau friend?", etc. In here the students get difficulties because they did not bring dictionary. That's why during the process, students always walked around the class to borrow the dictionary or asked the teacher and researcher to help them with it.

The role of teacher in here was clearly seen that the teacher at that time helped the students who got problem in their vocabulary and informed to them to bring dictionary in next meeting. 
Even there were some problems, based on the result of $2^{\text {nd }}$ draft the students also made an improvement after the third meeting was conducted. The students showed an improvement in part of language use but only few students who achieved the target. The students were able to produce composition based on generic structure of descriptive text. This problem was influenced by the way teacher in giving feedback to them. They did not understand because the teacher wrote the feedback in unorganized style.

Too many mistakes made them difficult to see the feedback within their sentences and sometimes did not know if there was feedback on theirs. Another problem was also shared by students about the teacher's comments. The teacher wrote the comments in English, so the students sometimes had difficulties to translate it into Indonesia.

Beside about students' problem in their composition, there were also several problems that affected the teaching and learning process, for example less of attention , less motivation to write, stuck with the ideas and sentences going to be developed, etc. In solving the problem, the next cycle will be conducted to solve those problems.

\section{Activities of the second cycle}

The result of the student's score in second cycle can be seen charts as follow :

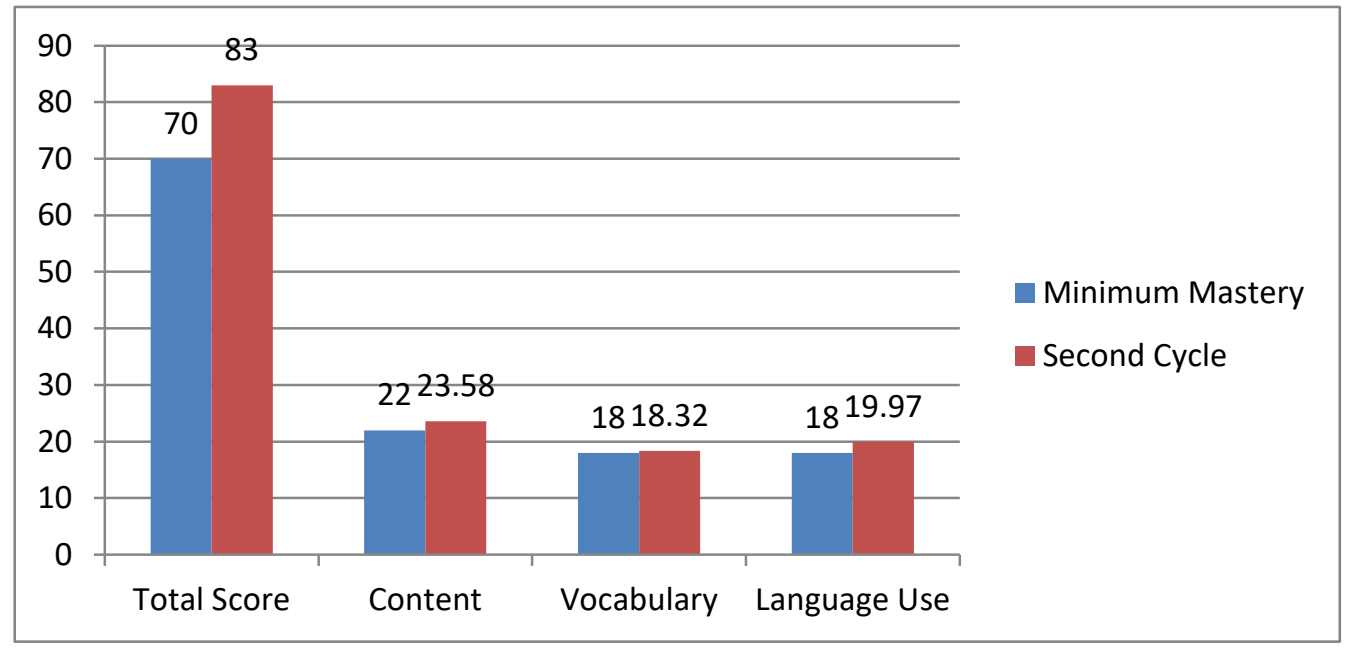

Chart.4.7 The students' mean score on second cycle result.

This chart is also like chart 4.1 and 4.4, it explaned about mean score of absolute range from three aspects of writing and total score of the student that researcher made on second cycle. The result of mean score from students' score devided by total of the students. The result has a good score and almost of the students have done of their writing significantly.

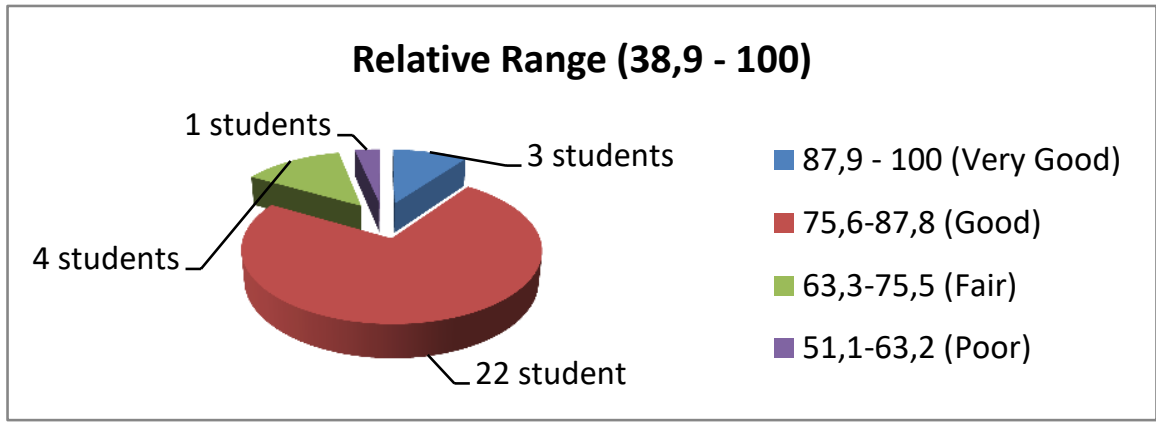

Chart.4.8. Total of the students' second cycle based on category 

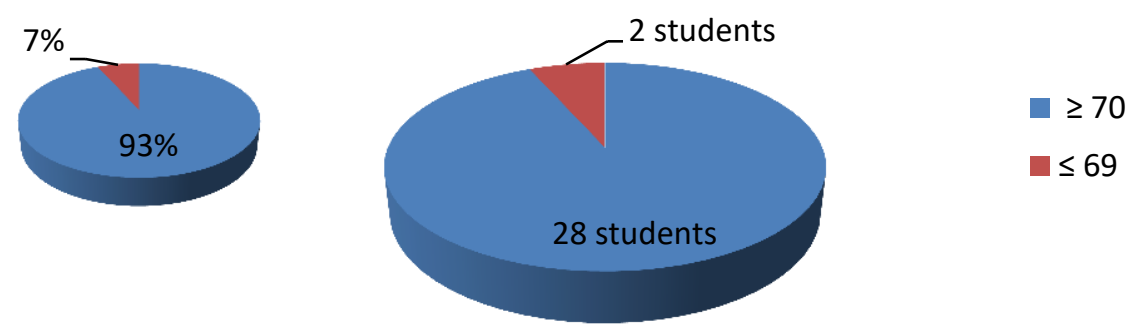

\section{Chart.4.9. The result of the students' second cycle based on minimum mastery}

This chart showed the significant result from the students if we compare the result between first cycle and second cycle. On first cycle, the researcher only gots 13 students or $43 \%$ of the students that was declared "Passed" in writing skill, but on second cycle, the researcher gots a good result. 28 students or $93 \%$ of the students showed a significant score of three aspect and they had been passed standard minimum of writing skill. Once again, it gives the strong impression that teacher's indirect feedback strategy can improve their writing.

In this cycle, there was actually no significant problem found since the solution from the teacher and researcher was successfully useful to students. The problems generally treated well since the solutions from teacher and researcher were successfully useful to students.

Based on observation in the second cycle, the result of $3^{\text {rd }}$ draft showed that they had good improvement during the process. They could compose $3^{\text {rd }}$ draft better than in the $1^{\text {st }}$ draft and $2^{\text {nd }}$ draft.

The teacher's strategy to use feedback sheet in their $2^{\text {nd }}$ draft was successful based on the result of their $3^{\text {rd }}$ drafts. There was only about their language choice produced by students where very Indonesian style like ".....he every lesson math always present...." It Should be "....he always presents in math class ......" This mistake corrected by teacher to explain the appropriate and encourages students understanding when interaction did. Even sometimes they still made it mistake in writing's aspects evaluation especially in organization or language use, but from their mistakes were decreased from draft 1 until draft 3 .

The progress of three steps (pre-assessment, $1^{\text {st }}$ cycle, and $2^{\text {nd }}$ cycle) can be seen the charts as follow:

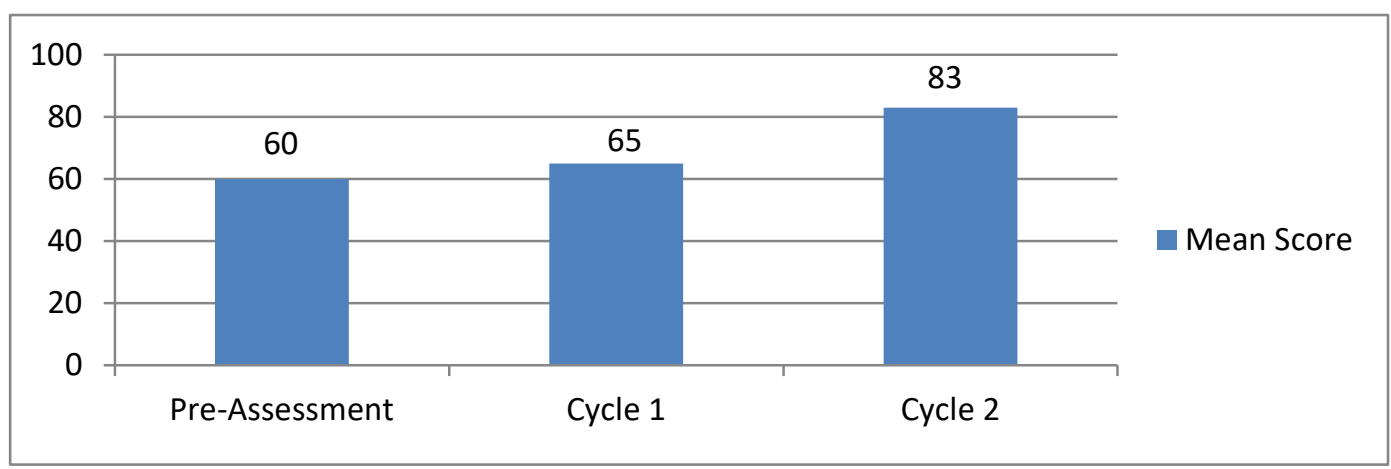

Chart.4.10 The Final Result of Three Steps Based on Score's Relative Range 


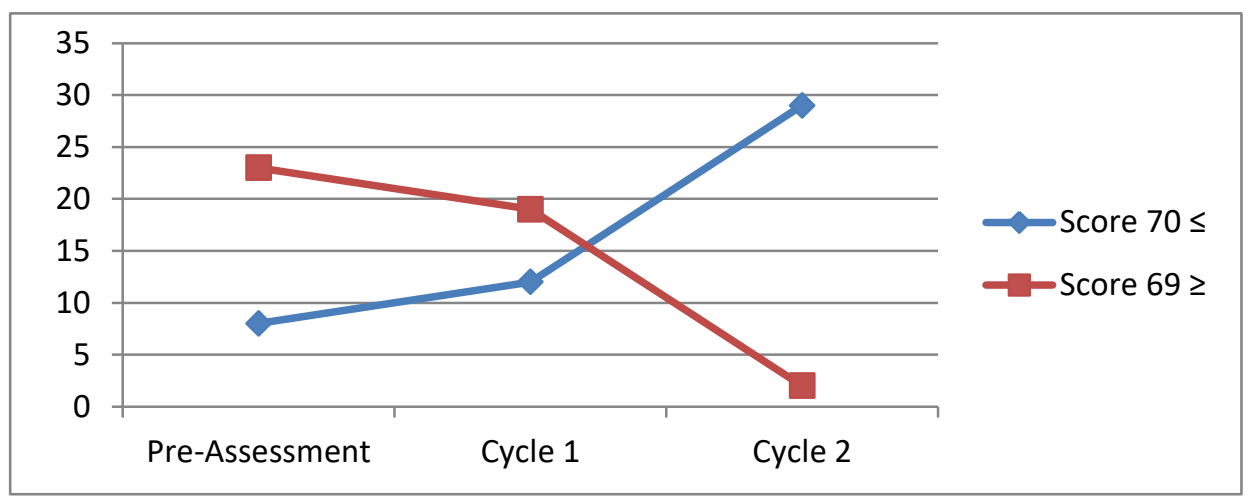

Chart.4.11 The Final Result of Three Steps

Both of charts showed a significant score that started by pre-assessment untill the last cycles. Minimum mastery of the students's writing had been improved also since using this strategy. It means this strategy could improve the students' ability in writing descriptive text.

The aim of this research was to prove that the students' ability can be improved through teacher's indirect feedback strategy. Beside that it helped students to be a good writer and become more confidence with their writing, especially in English. That is to encourage students to learn English through writing.

Seeing the students' draft in process from the first draft and the third draft, they indicate that there was improvement of students' writing during the process. It can be seen on students' composition on first draft. In the first draft, mostly students wrote disorder language use of text and irrelevant with what they wanted to write. The major problem was language use, particularly the use of present tense in their composition, word order, word choice, etc.

Before starting the research, the researcher did pre-observation and the result was almost of the students had some problems of three aspects in writing. The researcher conducted the research in two cycles. The first cycle consists of four meeting and students made two drafts. While, in the second cycle consists of four meetings also and students made their final draft in the eighth meeting.

The teacher taught writing by using genre based approach, which consists of preparation, modeling, joint construction and independent construction. After finishing their writing in each meeting, the teacher took those compositions and provided the feedback. In this study, the researcher collaborated with the English teacher to give indirect feedback on their writing. To evaluate the students' writing, the teacher and researcher used the evaluation proposed by Holly Jacob, et al (1981:67) of three components; Content, Vocabulary, and Language Use. The text used is descriptive text.

The last was interview. Interview was done when the cycles were end. The researcher had interviewed all the students at grade X IPA 1 of SMAN 1 Bengkulu Tengah to know their opinion about following the lesson which implemented teacher's indirect feedback strategy.

The finding of students' interview indicated that teacher's indirect feedback strategy was really useful for the students. They could find the mistakes and then revise their writing to be better after reading suggestion from the teacher. Thus, teacher's indirect feedback strategy helped the students to revise their writing even though the students needed longer time.

The researcher concluded that teacher's indirect feedback strategy helped the students at grade X IPA 1 of SMAN 1 Bengkulu Tengah in improving their ability in writing descriptive text. teacher's indirect feedback strategy also influenced students' attention, interaction, respectability, activeness, and enthusiasm in teaching and learning process. 


\section{CONCLUSION}

Based on the finding, it can be conclued that:

1. The implementation of teacher's indirect feedback strategy in teaching writing can be used by the teacher as one of ways to improve students' writing quality. It can be seen on students' progress during the process (Pre-assessment, $1^{\text {st }}$ cycle, and $2^{\text {nd }}$ cycle).

2. The extent of teacher's indirect feedback strategy to the students' writing ability was significant score in writing. This improvement was also supported by the comparison of number students who got score upper 70 before and after the action was conducted. Before the action was conducted, the students who categorized 70 $\leq$ were 8 students and the other students got $69 \geq$.

On the other hand, after students were treated by teacher's indirect feedback strategy into first and second cycles, total of the students who categorized in $70 \leq$ increased become 29 students and just 2 students got $69 \geq$. From those comparisons, it indicated that the improvement of students' writing performance was achieved by applying teacher's indirect feedback strategy.

3. The students' responses of teacher's indirect feedback strategy can be accepted by them and good respons. They felt this strategy was very helpful to improve their writing skill.

\section{BIBLIOGRAPHY}

Adelstein, M.M.E. Pival J. G. 2010. The Writing Commitment. New York. http://books.google.co.id/books/about/The_writing_commitment.html

Arikunto, Suharsimi, dan Suharjo, dan Supardi. 2008. Penelitian Tindakan Kelas. Jakarta : PT Bumi Aksara.

Bratcher, Suzanne \& Ryan, Linda. 2004. Evaluating Children's Writing, A Hanbook of Grading Choices for Classroom Teachers: Second Edition. New Jersey: Lawrence Erlbaum Associates, Inc.

Broad, Bob. 2003. What We Really Value, Beyond Rubrics in Teaching and Assessing Writing . Utah: Utah State University Press.

Brown, H. Douglas. 2000. Teaching by Principles: An Interactive Approach to Language Pedagogy (2nd Ed.). New York: Longman.

Byrne, Donn. 2004. Teaching Writing Skills. England: Essex. Longman.

Celce-murcia, Marriane. 2001. Teaching English as a second or foreign Language. US: Thompson Learning. 
Dunsford, Deborah W. (2006). Feedback Follow up: The Influence of Teacher Comment on Student Writing Assignments. NACTA Journal June 2006. Retrieved from http:// www.findarticles.com/p/articles/mi qa/

Fregeau, L. A. (2007). Preparing ESL Students for College Writing: Two Case studies. The Internet TESL Journal [On-Line], 5 (10). Retrieved On March $26^{\text {th }}, 2014$. Available : http://iteslj.org/Articles/Fregeau-CollegeWriting.html

Graham, Steve and Dolores, Perin. 2007. Effect Strategies to Improve writing of Adolecents in Middle and Schools. New York: Carnegie Corporation.

Harmer, Jeremy. 2001. The Practice of English Language Teaching. England: Person Education Limited.

Hegarty, Carol. 2000. Writing; English in Context. United States of America: Saddleback Education Publishing.

Hikmah, Faridatul. 2012. Improving The Students' Writing Skill by Using Cue Cards. Skripsi. Surakarta: English Education Department Graduate School Sebelas Maret University.

Kane, Thomas S. 2000. The Oxford Essential Guide to Writing . New York: Barkley Books.

Kepner, C. G. (2001). An experiment in the relationship of types of written feedback to the development of second-language writing skills. Modern Language Journal, 75(3), 305-313.

Kusmita, Endang. 2010. Improving Students's Ability in Writing Descriptive Paragraph by using Pictures. Skripsi. Bengkulu. English Education Study Program Tarbiyah department of STAIN Bengukulu.

Lalande, J. F. (2002). Reducing composition errors: An experiment. Modern Language Journal, 66(1), 140-149.

Lee, Icy. (2005). Enhancing the Effectiveness of Teacher Feedback in the Secondary Writing Classroom. Chinese University of HongKong. Retrieved on March $8^{\text {th }}, 2013$. Available : http://sba.edu.hku.hk/new_sba/doc/conference_ppt/Dr\%20Icy\%20Lee.ppt.

Lennon, Johnn . 2011 . The Writing Process : A Concise Rhetoric : Fourth Edition , New York : Harpes Collins Publisher .

Lieberman, Ann \& Wood, Diane R. 2003. Inside National Writing Project; Connecting Network Learning and Classroom Teaching. New York: Teacher College Press.

Lindbllom, Peter. 2003. Writing with Confidence. New York: Harper Collins Publisher.

Littlejohn, Andrew. 2005. Writing Student's Book 1. Cambridge: Cambridge University Press

Littell, Joy. 2001. Basic Skills in English. New York: McDonal, Littell\& Company. 
Nadler, Burton Jay et. al. 2005.Words You Should Know in High School, 1,000 Essential Words to Build Vocabulary, Improve Standardized Test Scores, and Write Successful Papers. Massachusetts: Adams Media.

Nahdiah, Usman. 2010. Implementation of Direct Method to Improve Vocabulary Mastery of the Elementary School of SDI 103 SDI 103 Sompu. Thesis. FKIP UMM Makassar.

Nunan, David. 2003. Practical English language Teaching (1st Ed.). New York: Longman

Olson, Judith F. 2009. Writing Skills Success in 20 Minutes a Day. New York: Learning Express.

Rochberg, Francesca. 2004. The Heavenly Writing; Divination, Horoscopy, and Astronomy in Mesopotamian Culture. Cambridge: Cambridge University Press.

Roger, Jenny. (2001). In Adults Learning; Buckingham: Open University Press (online). Retrieved from: http:// www.findarticles.com/ articles/feedback/.

Santi, dewi. 2007. The Effect Of Teacher's Feedback on 2005 English Major Student Writing at Haluoleo University. FKIP Universitas Haluoleo Kendari.

Sudjana, Nana. (1989). Penelitian Hasil Proses Belajar Mengajar. Bandung: PT. Remaja Rosda Karya.

Syaparuddin, Talib. 2010. Improving the students' writing narrative paragraph through guided question technique. Thesis. FKIP UMM Makassar.

Tarigan, HG. 1996. Menulis Sebagai Suatu Keterampilan Berbahasa. Bandung: Angkasa.

Ur, Penny. (1996). A Course in Language Teaching. USA: Cambridge University Press.

Weigle, Sara Cushing. 2002. Assessing Writing. Cambridge: Cambridge University Press.

Yuharniaty. U. 2007. Implementation of Portofolio Assessment to Increase the Students' Writing Skill. Skripsi. Makassar : Fakultas Bahasa dan Seni Universitas Negeri Makassar. 